\title{
The Effects of Accelerating Admixture on the Mechanical Properties of Boric Acid Added Mortars
}

\author{
M. Davraz, Ş. KilinÇARslan And E. PehlivanoĞLU \\ Natural and Industrial Building Materials Application and Research Center, Suleyman Demirel University \\ Isparta, Turkey
}

\begin{abstract}
Use of boron compounds has not become widespread because of the hardening and the other related problems in cementitious composites. The boron compounds as an additive material can be used widely in the production of cement and concrete in case of the elimination of these negative conditions. Thus the control of workability and hydration process of fresh concrete and mortar, some technological properties such as fire resistance, the radiation impermeability of hardened concrete and mortars can be enhanced. In this study, the effects of accelerating admixtures to the mechanical properties of boric acid added mortars were investigated. In order to determine of these effects and the results obtained to compare with those of control mortars, prismatic mortar samples were prepared in accordance with TS 196-1. Boric acid was added to mortar samples by up to $1 \%$ from $0.25 \%$ by weight of cement. Boric acid was not added to control mortar samples. Portland cement, boron modified active belite cement and calcium aluminate cement as binding material were used in mortar samples. 2, 7, 28 day compressive strengths and 28 day flexural strengths of 315 prismatic samples which were prepared in accordance with the design of 35 different mixes were determined. Results of boric acid added mortar samples were compared with control samples produced by using Portland cement, BAB cement and CAC cement. 2, 7, and 28 day compressive/ flexural strength of mortar samples which were added $1 \%$ boric acid was determined as $0 / 0,12.8 / 2.90,40 / 6 \mathrm{MPa}$, respectively. Other hand, 2, 7, and 28 day compressive/flexural strength of mortar samples which were added $1 \%$ boric acid and $2 \%$ sodium aluminate was determined as $14.2 / 3.07,27.2 / 5.57,34.2 / 5.97 \mathrm{MPa}$, respectively. As a result, the retarding effect of the boric acid in terms of early strength of concrete was suppressed using sodium aluminate.
\end{abstract}

DOI: 10.12693/APhysPolA.125.263

PACS: 81.05.Mh

\section{Introduction}

Boron-containing wastes of nuclear power plants have been solidified using cement and stored underground for many years. However, the compressive strengths of these concretes are limited with 8-10 $\mathrm{MPa}$, and it can take 90 days reaching to this strength value. In the other word, the negative effect of boron compounds on cement hydration is well-known phenomenon. These effects can be described as the increase of hydration time, a much reduction of early strength, weakening of cementaggregate bond strength, solidification-hardening problems and strength-durability problems.

Phenomena which are caused by these effects can be explained as follows: calcium borate $\left(\mathrm{CaOB}_{2} \mathrm{O}_{3}\right)$ occur with reacting of boron oxide $\left(\mathrm{B}_{2} \mathrm{O}_{3}\right)$ and calcium hydrate $(\mathrm{CaOH})$ which are formed during interaction of cement with mixing water. This compound is cover to surface of cement particles partially or completely. As a result, the hydration reaction of cement is interrupted.

In recent years, many studies have been carried out for the usability of boron wastes at the cement production. Kula et al. (2002) have mentioned that the use of tincal ore waste also gives rise to an improvement in the properties of Portland cement (OPC) at 1\% replacement level. Although it retards setting time, it gives an opportunity for use as a cement replacement material up to $5 \mathrm{wt} \%$ of the cement [1]. According to Targan et al. (2003), the compressive strength of concrete samples is made by cement with grinding the $81-96 \%$ Portland clinker, $4 \%$ colemanite waste, and $5-15 \%$ natural pozzolan materials at 90 days of curing performs $90 \%$ of control concrete samples. They also stated that the 28 days strengths of concrete made by high pozzolan cements including colemanite waste are higher than that of the concrete samples by low pozzolan cements [2].

In 2006 year, the boron modified active belite cement (BAB) with using colemanite ore was produced at Goltaş Cement Factory in Isparta, Turkey. According to researches based on this cement type, this cement with no alite $\left(\mathrm{C}_{3} \mathrm{~S}\right)$ phase could be successfully used specially in dam concretes due to its very low hydration temperature. In addition, the final compressive strength of concrete made by $\mathrm{BAB}$ cement is much higher than concrete's made by OPC [3].

In addition, properties such as shrinkage and fire resistibility of concrete and cementitious other composites including boron compounds in appropriate concentrations may be improved. Furthermore, these products may also gain new features such as radiation impermeability and antibacteriality. In some research, Volkman and Bussolini (1992) have stated that the boron compounds adding to concrete absorbs the neutrons and low energy gamma rays spreads. Therefore, it could be supplied as an effective radiation protection. However, adding boron seriously retards the setting time and decreases the concrete strength [4]. 
Physical and chemical properties of cements used as a binder [9, 10].

\begin{tabular}{|c|c|c|c|c|c|c|c|}
\hline \multicolumn{4}{|c|}{ Chemical properties of clinkers } & \multicolumn{4}{|c|}{ Physical properties of cements } \\
\hline Components [\%] & $\mathrm{OPC}$ & $\mathrm{BAB}$ & CAC & & OPC & $\mathrm{BAB}$ & $\mathrm{CAC}$ \\
\hline $\mathrm{SiO}_{2}$ & 20.52 & 20.37 & 2.20 & volumetric expansion [mm] & 1 & 0 & 0 \\
\hline $\mathrm{Al}_{2} \mathrm{O}_{3}$ & 4.00 & 4.45 & 40.70 & fineness $[90 \mu]$ & 0.1 & 0.1 & 6.5 \\
\hline $\mathrm{Fe}_{2} \mathrm{O}_{3}$ & 3.45 & 3.27 & 17.00 & slightness $[200 \mu]$ & 1.1 & 1.8 & 1.2 \\
\hline $\mathrm{CaO}$ & 64.28 & 58.19 & 38.20 & specific surface area $\left[\mathrm{cm}^{2} / \mathrm{g}\right]$ & 3340 & 3560 & 3540 \\
\hline $\mathrm{MgO}$ & 1.63 & 4.70 & 0.80 & initial setting time [min] & 185 & 220 & 245 \\
\hline $\mathrm{SO}_{3}$ & 2.53 & 3.08 & 0.02 & final setting time [min] & 240 & 265 & 265 \\
\hline $\mathrm{Na}_{2} \mathrm{O}+\mathrm{K}_{2} \mathrm{O}$ & 1.35 & 1.50 & 0.07 & specific gravity $\left[\mathrm{g} / \mathrm{cm}^{3}\right]$ & 3.12 & 2.98 & 3.29 \\
\hline $\mathrm{B}_{2} \mathrm{O}_{3}$ & 0.00 & 1.12 & 0.00 & flexural strength (MPa, at 2 days) & 4.5 & 2.5 & $6.0^{a}$ \\
\hline $\mathrm{CaO}$ (free) & 1.81 & 0.63 & - & flexural strength (MPa, at 7 days) & 5.8 & 4.1 & $7.5^{b}$ \\
\hline L.O.I. & 2.72 & 4.02 & 0.30 & flexural strength (MPa, at 28 days) & 7.2 & 6.0 & $9.5^{c}$ \\
\hline \multicolumn{4}{|c|}{ Clinker phases [\%] } & compressive strength (MPa, at 2 days) & 11.7 & 11.7 & $55.2^{d}$ \\
\hline $\mathrm{C}_{3} \mathrm{~S}$ & - & 56.66 & & compressive strength ( $\mathrm{MPa}$, at 7 days) & 39.3 & 23.2 & 81.6 \\
\hline $\mathrm{C}_{2} \mathrm{~S}$ & 66.23 & 17.65 & & compressive strength ( $\mathrm{MPa}$, at 28 days) & 51.0 & 38.6 & - \\
\hline $\mathrm{C}_{3} \mathrm{~A}$ & 7.86 & 6.33 & & \multicolumn{4}{|c|}{ Other properties of cements } \\
\hline $\mathrm{C}_{4} \mathrm{AF}$ & 14.01 & 12.03 & & $\mathrm{Cl}^{-}$ & 0.000 & 0.006 & 0.000 \\
\hline
\end{tabular}

${ }^{a} 6$ hours; ${ }^{b} 24$ hours; ${ }^{c} 6$ hours; ${ }^{d} 24$ hours

On the other hand, Demir and Keleş (2006) have prepared the concrete samples including borogypsum and colemanite concentrator wastes. They tested the differences in gamma rays passing energies for normal and boron waste added concretes samples. They observed that concrete samples including boron wastes supply an effective protection against radioactive radiations [5]. National Boron Research Institution (BOREN) stated that $\mathrm{BAB}$ cement has more than $20 \%$ of a neutron absorbing capacity compared to OPC [6]. Çelik (2008) also has stated that cellulose insulation materials including approximately $20 \% \mathrm{~B}(\mathrm{OH})_{3}$ or borax are more resistant up to $57 \%$ against fire. They have also killing capacity up to $99.8 \%$ against micro-organisms and insects [7].

The improvements and additional features which are provided by boron compounds to concrete and cementitious composites are very closely relevant to $\mathrm{B}_{2} \mathrm{O}_{3}$ concentrations of using boron compounds. Furthermore, it is intensively researched a phenomenon, when the cement hydration slows down and even stops with the increase of $\mathrm{B}_{2} \mathrm{O}_{3}$ concentration and the setting time of mortar increases related to the situation [8].

In this study, there was investigated the effect of anhydrous boric acid as additive material on the compressive and flexure strengths of mortar samples which are produced with different cements. In addition, we tried to suppress the effect of the boron compound on the especially early strength of some mortar samples by using accelerator additives.

\section{Material and methods}

Boric acid (BA) obtained from Eti Mine Works as a source of $\mathrm{B}_{2} \mathrm{O}_{3}$, OPC, and $\mathrm{BAB}$ cement obtained from Göltaş Cement Factory and calcium aluminate cement (CAC) obtained from CIMSA were used in this study.
Also accelerator additive materials such as calcium chloride $(\mathrm{CC})$, sodium aluminate $(\mathrm{SA})$ were added in the mortar mixtures in order to suppress the retarding effect of boric acid to cement hydration. The dosages of cement (PC, BAB, or $\mathrm{CAC}$ ) used in all mortar samples are equal. The grain size distribution of CEN standard sand were used as aggregate, and physical and chemical properties of $\mathrm{PC}, \mathrm{BAB}$, and $\mathrm{CAC}$ cements using as a binder were given in Tables I and II, respectively.

\section{TABLE I}

The grain size distribution of CEN standard sand.

\begin{tabular}{c|c}
\hline $\begin{array}{c}\text { Sieve mesh } \\
\text { size }[\mathrm{mm}]\end{array}$ & $\begin{array}{c}\text { Cumulative percent } \\
\text { retained sieve [\%] }\end{array}$ \\
\hline 2.00 & 0 \\
1.60 & 6 \\
1.00 & 35 \\
0.50 & 68 \\
0.16 & 89 \\
0.08 & 99
\end{tabular}

TABLE III

The amounts of materials used in the mortar mixes (for three pieces).

\begin{tabular}{c|c}
\hline \hline Components & Amount [g] \\
\hline cement & $450 \pm 2$ \\
standard sand & $1350 \pm 5$ \\
water & $450 \pm 1$
\end{tabular}

Mortar mixtures were prepared in accordance with TS EN 196-1 standard. Mortar mixture designs for 3 pcs prisms (one set) were given in Table III.

Except for the control mortar samples, boric acid was added to mortar mixtures at $0.25 \%, 0.5 \%, 0.75 \%$ and $1 \%$ 
by weight of cement

$$
2 \mathrm{~B}[\mathrm{OH}]_{3}+\text { heat } \rightarrow \mathrm{B}_{2} \mathrm{O}_{3}+3 \mathrm{H}_{2} \mathrm{O} \text {. }
$$

If $2 \mathrm{~mol}$ of $\mathrm{B}[\mathrm{OH}]_{3}$ is heated up to $600{ }^{\circ} \mathrm{C}$ approximately, $1 \mathrm{~mol}$ of $\mathrm{B}_{2} \mathrm{O}_{3}$ and $3 \mathrm{~mol}$ of water occurs. As $1 \mathrm{~g}$ of $\mathrm{B}[\mathrm{OH}]_{3}$ is heated, approximately $0.577 \mathrm{~g}$ of $\mathrm{B}_{2} \mathrm{O}_{3}$ is obtained. For mortar samples which were added boric acid, $\mathrm{B}_{2} \mathrm{O}_{3}$ amount was calculated according to Eq. (2):

$$
M_{\mathrm{B}_{2} \mathrm{O}_{3}}=c \times 0.02 \times 0.577,
$$

where $M_{\mathrm{B} 2 \mathrm{O} 3}$ - amount of $\mathrm{B}_{2} \mathrm{O}_{3}$ included in boric acid added mortar samples $(\mathrm{g}), c$ - cement dosage $(\mathrm{g})$.

After determination of $\mathrm{B}_{2} \mathrm{O}_{3}$ amount, $W_{\mathrm{B} 2 \mathrm{O} 3} / c$ ratios for each set of samples were calculated as $0.144,0.288$, 0.434 , and 0.577 , respectively. In addition, the accelerator additives (sodium aluminate, calcium chloride) were added at rates of $1.0 \%, 1.5 \%, 2 \%$ by weight of cement in order to suppress of retarding effect of boric acid (Table IV).

Amount of cement type, boric acid and chemical admixture used in mortar samples.

\begin{tabular}{|c|c|c|c|c|c|c|}
\hline Sample No. & \multicolumn{2}{|c|}{ Cement type } & $W_{\mathrm{BA}} / c[\%]$ & $W_{\mathrm{B} 2 \mathrm{O} 3} / c$ & AA type & $W_{\mathrm{AA}} / c[\%]$ \\
\hline $\mathrm{P}$ & \multicolumn{2}{|c|}{ Portland } & 0 & 0.00 & - & - \\
\hline $\mathrm{B}$ & \multicolumn{2}{|c|}{ boron modified active belite } & 0 & 1.112 & - & - \\
\hline $\mathrm{C}$ & \multicolumn{2}{|c|}{ calcium aluminate } & 0 & 0.00 & - & - \\
\hline $\mathrm{Pb} 1$ & \multicolumn{2}{|c|}{ Portland } & 0.25 & 0.144 & - & - \\
\hline $\mathrm{Pb} 2$ & \multicolumn{2}{|r|}{ Portland } & 0.50 & 0.288 & - & - \\
\hline $\mathrm{Pb} 3$ & \multicolumn{2}{|r|}{ Portland } & 0.75 & 0.434 & - & - \\
\hline $\mathrm{Pb} 4$ & \multicolumn{2}{|r|}{ Portland } & 1.00 & 0.577 & - & - \\
\hline Cb1 & \multicolumn{2}{|c|}{ calcium aluminate } & 0.25 & 0.144 & - & - \\
\hline $\mathrm{Cb} 2$ & \multicolumn{2}{|c|}{ calcium aluminate } & 0.50 & 0.288 & - & - \\
\hline $\mathrm{Cb} 3$ & \multicolumn{2}{|c|}{ calcium aluminate } & 0.75 & 0.434 & - & - \\
\hline $\mathrm{Cb} 4$ & \multicolumn{2}{|c|}{ calcium aluminate } & 1.00 & 0.577 & - & - \\
\hline $\mathrm{Pb} 1 \mathrm{c} 1$ & \multicolumn{2}{|c|}{ Portland } & 0.25 & 0.144 & calcium chloride & 1.0 \\
\hline $\mathrm{Pb} 2 \mathrm{c} 1$ & \multicolumn{2}{|r|}{ Portland } & 0.50 & 0.288 & calcium chloride & 1.0 \\
\hline $\mathrm{Pb} 3 \mathrm{c} 1$ & \multicolumn{2}{|r|}{ Portland } & 0.75 & 0.434 & calcium chloride & 1.0 \\
\hline $\mathrm{Pb} 4 \mathrm{c} 1$ & \multicolumn{2}{|r|}{ Portland } & 1.00 & 0.577 & calcium chloride & 1.0 \\
\hline $\mathrm{Pb} 1 \mathrm{c} 2$ & \multicolumn{2}{|r|}{ Portland } & 0.25 & 0.144 & calcium chloride & 1.5 \\
\hline $\mathrm{Pb} 2 \mathrm{c} 2$ & \multicolumn{2}{|r|}{ Portland } & 0.50 & 0.288 & calcium chloride & 1.5 \\
\hline $\mathrm{Pb} 3 \mathrm{c} 2$ & \multicolumn{2}{|r|}{ Portland } & 0.75 & 0.434 & calcium chloride & 1.5 \\
\hline $\mathrm{Pb} 4 \mathrm{c} 2$ & \multicolumn{2}{|r|}{ Portland } & 1.00 & 0.577 & calcium chloride & 1.5 \\
\hline $\mathrm{Pb} 1 \mathrm{c} 3$ & \multicolumn{2}{|r|}{ Portland } & 0.25 & 0.144 & calcium chloride & 2.0 \\
\hline $\mathrm{Pb} 2 \mathrm{c} 3$ & \multicolumn{2}{|r|}{ Portland } & 0.50 & 0.288 & calcium chloride & 2.0 \\
\hline $\mathrm{Pb} 3 \mathrm{c} 3$ & \multicolumn{2}{|r|}{ Portland } & 0.75 & 0.434 & calcium chloride & 2.0 \\
\hline $\mathrm{Pb} 4 \mathrm{c} 3$ & \multicolumn{2}{|r|}{ Portland } & 1.00 & 0.577 & calcium chloride & 2.0 \\
\hline $\mathrm{Pb} 1 \mathrm{~s} 1$ & \multicolumn{2}{|r|}{ Portland } & 0.25 & 0.144 & sodium aluminate & 1.0 \\
\hline $\mathrm{Pb} 2 \mathrm{~s} 1$ & \multicolumn{2}{|r|}{ Portland } & 0.50 & 0.288 & sodium aluminate & 1.0 \\
\hline $\mathrm{Pb} 3 \mathrm{~s} 1$ & & Portland & 0.75 & 0.434 & sodium aluminate & 1.0 \\
\hline $\mathrm{Pb} 4 \mathrm{~s} 1$ & & Portland & 1.00 & 0.577 & sodium aluminate & 1.0 \\
\hline $\mathrm{Pb} 1 \mathrm{~s} 2$ & & Portland & 0.25 & 0.144 & sodium aluminate & 1.5 \\
\hline $\mathrm{Pb} 2 \mathrm{c} 2$ & & Portland & 0.50 & 0.288 & sodium aluminate & 1.5 \\
\hline $\mathrm{Pb} 3 \mathrm{~s} 2$ & & Portland & 0.75 & 0.434 & sodium aluminate & 1.5 \\
\hline $\mathrm{Pb} 4 \mathrm{~s} 2$ & & Portland & 1.00 & 0.577 & sodium aluminate & 1.5 \\
\hline $\mathrm{Pb} 1 \mathrm{~s} 3$ & & Portland & 0.25 & 0.144 & sodium aluminate & 2.0 \\
\hline $\mathrm{Pb} 2 \mathrm{~s} 3$ & & Portland & 0.50 & 0.288 & sodium aluminate & 2.0 \\
\hline $\mathrm{Pb} 3 \mathrm{~s} 3$ & & Portland & 0.75 & 0.434 & sodium aluminate & 2.0 \\
\hline $\mathrm{Pb} 4 \mathrm{~s} 3$ & & Portland & 1.00 & 0.577 & sodium aluminate & 2.0 \\
\hline P: Port & land cemer & & BAB cement & & C: calcium alumin & e cement \\
\hline $\mathrm{b} 1:\left(W_{\mathrm{B} 2 \mathrm{O} 3}\right)$ & $c=0.144)$ & $\mathrm{b} 2:\left(W_{\mathrm{B} 2 \mathrm{O} 3} / c=0\right.$ & \begin{tabular}{l|l}
$288)$ & b3: ( \\
\end{tabular} & $\mathrm{B} 2 \mathrm{O} 3 / c=$ & \begin{tabular}{l|l}
$434)$ & $\mathrm{b} 4:\left(W_{\mathrm{B} 2 \mathrm{O}}\right.$ \\
\end{tabular} & $c=0.577)$ \\
\hline c1: calciu & $\mathrm{n}$ chloride, & \begin{tabular}{l|l}
$1 \%$ & $\mathrm{c} 2: \mathrm{cal}$ \\
\end{tabular} & um chloride, & $1.5 \%$ & c3: calcium chlor & e, $2.0 \%$ \\
\hline s1: sodium & aluminate & s2: sodi & $\mathrm{m}$ aluminate & $1.5 \%$ & s3: sodium alumir & tee, $2.0 \%$ \\
\hline
\end{tabular}

TABLE IV

The prepared mortars were poured into the moulds having dimension of $40 \times 40 \times 160 \mathrm{~mm}^{3}$, compressed, and removed from the moulds after one day. The samples removed from the moulds were cured at $20^{\circ} \mathrm{C}$ in water until the time of testing. The flexural and compressive strengths of mortar samples at 2,7 , and 28 days were determined in accordance with TS EN 196-1 standard [11]. The flexural and compressive strengths of these samples 
were calculated using Eqs. (3) and (4), respectively

$$
R_{\mathrm{f}}=1.5 F \times \frac{L}{b^{3}},
$$

where $R_{\mathrm{f}}$ - flexural strength, MPa, $b$ - the side length of square cross-section of prism, mm, $F$ - the force applied to center of the prism at breaking time, N, $L$ - the distance between the support rollers, $\mathrm{mm}$.

$$
R_{\mathrm{c}}=\frac{F_{\mathrm{c}}}{1600},
$$

where $R_{\mathrm{c}}$ - compressive strength, $\mathrm{MPa}, F_{\mathrm{c}}$ - the maximum load at the time of failure, N, 1600 - the area of plates used in the experiment $\left(40 \times 40 \mathrm{~mm}^{2}\right)$.

\section{Results and discussion}

The results of compressive strengths of mortar samples at 2, 7, and 28-d were given in Fig. 1. C sample has the highest $28-\mathrm{d}$ compressive strength $\left(f_{\mathrm{c}-28 \mathrm{~d}}\right)$ between the control samples. However, $f_{\mathrm{c}-2 \mathrm{~d}}, f_{\mathrm{c}-7 \mathrm{~d}}$, and $f_{\mathrm{c}-28 \mathrm{~d}}$ values of $\mathrm{P}$ control samples were higher than values of $\mathrm{B}$ control samples. The mortar samples of $\mathrm{Cb} 1, \mathrm{Cb} 2$ and Cb3 having $\mathrm{B}_{2} \mathrm{O}_{3} / c \leq 0.434$ ratios were not solidified at 2 and 7 days. Similarly, the mortar sample of $\mathrm{Cb} 4$ having $\mathrm{B}_{2} \mathrm{O}_{3} / c=0.577$ ratio was not solidified at 28 days. While $\mathrm{Pbc}$ samples reached the highest 28-d compressive strengths $\left(f_{\mathrm{c}-28 \mathrm{~d}}\right), \mathrm{Pbs}$ samples showed the highest flexural strengths $\left(f_{\mathrm{c}-2 \mathrm{~d}}\right.$ and $\left.f_{\mathrm{c}-7 \mathrm{~d}}\right)$ at 2 and 7 days among the mortar samples used in the Portland cement and additives.

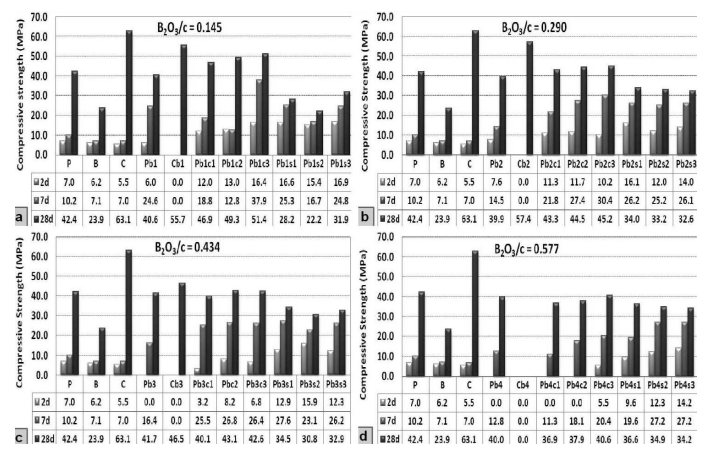

Fig. 1. 2, 7 and 28-d compressive strength of control $(\mathrm{P}, \mathrm{B}, \mathrm{C})$ and mortar samples with additive.

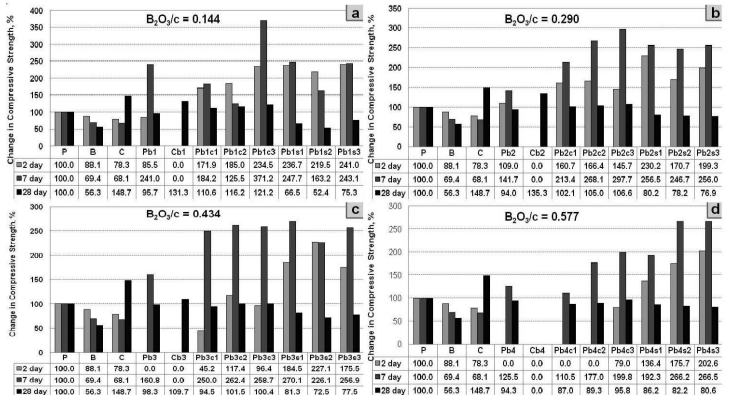

Fig. 2. The changes of compressive strengths of mortar samples with additive in comparison with $\mathrm{P}$ control sample.

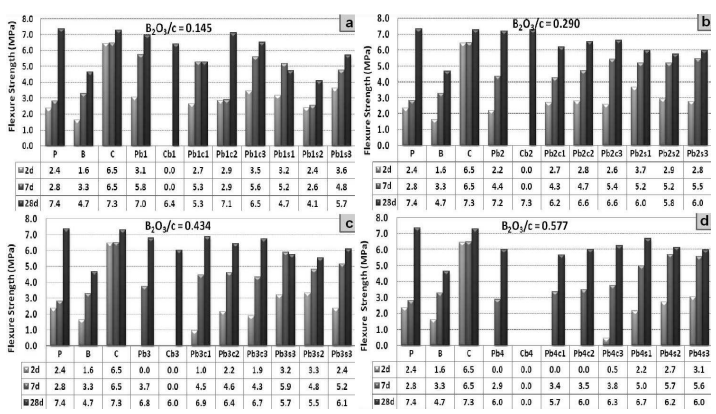

Fig. 3. 2, 7 and 28-d flexural strength of control $(\mathrm{P}, \mathrm{B}, \mathrm{C})$ and mortar samples with additive.

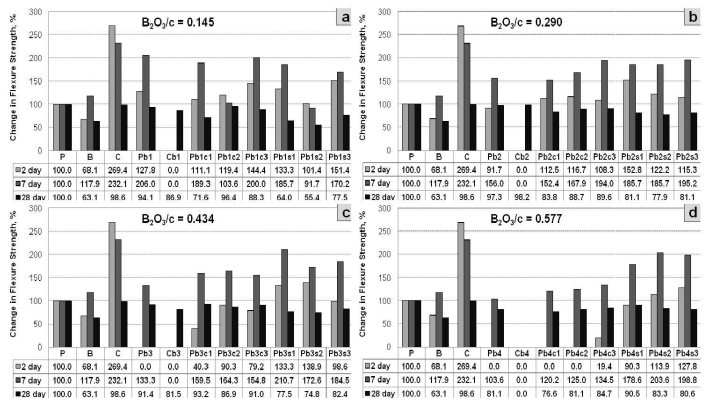

Fig. 4. The changes of flexural strengths of mortar samples with additive according to $\mathrm{P}$ control sample.

In addition, the changes $\left(\Delta f_{\mathrm{c}}\right)$ of compressive strengths of mortar samples with additive in comparison with $\mathrm{P}$ control sample at 2, 7 and 28 -d were given in Fig. 2. $\Delta f_{\mathrm{c}-28 \mathrm{~d}}$ ratio of $\mathrm{Pbc}$ samples is the highest between mortar samples with additive in comparison with $\mathrm{P}$ control sample. On the other hand, $\mathrm{Pbs}$ samples have the highest $\Delta f_{\mathrm{c}-2 \mathrm{~d}}$ and $\Delta f_{\mathrm{c}-7 \mathrm{~d}}$ ratios at $\mathrm{B}_{2} \mathrm{O}_{3} / c \geq 0.434$ ratios.

The results of flexural strengths of mortar samples at 2, 7 and 28-d were given in Fig. 3. $P$ and $C$ have the highest $28-\mathrm{d}$ compressive strength $\left(f_{\mathrm{cf}-28 \mathrm{~d}}\right)$ between the control samples. The highest $f_{\mathrm{cf}-28 \mathrm{~d}}$ value is belonged to $P b 3 c 1$ sample, the highest $f_{\mathrm{c}-2 \mathrm{~d}}$ value belongs to $P b 3 s 2$ sample and the highest $f_{\mathrm{c}-7 \mathrm{~d}}$ value also belongs to $P b 3 s 3$ sample between mortar samples with Portland cement.

The changes $\left(\Delta f_{\text {cf }}\right)$ of flexural strengths of mortar samples with additive in comparison with $P$ control sample at 2, 7 and 28-d were given in Fig. 4. Pbc samples have the highest $\Delta f_{\mathrm{cf}-28 \mathrm{~d}}$ ratios between mortar samples with additive in comparison with $P$ control samples (except for $\mathrm{B}_{2} \mathrm{O}_{3} / c \leq 0.577$ ratio). On the other hand, the highest $\Delta f_{\mathrm{cf}-2 \mathrm{~d}}$ and $\Delta f_{\mathrm{cf}-7 \mathrm{~d}}$ ratios belong to $\mathrm{Pbs}$ samples at $\mathrm{B}_{2} \mathrm{O}_{3} / c \geq 0.434$ ratios.

\section{Conclusion}

The negative effect of boron compounds on the early strength of cemented composites is well known. In this study, there was investigated the effect of boric acid compound to the compressive and flexural strengths of mortar samples at 2, 7 and 28-d. In addition, accelerator 
additive materials in mortar samples were used for suppressing this effect.

For $\mathrm{B}_{2} \mathrm{O}_{3} / c \leq 0.290$ ratio, the compressive and flexural strengths of mortar samples in 2 and 7 -d are reduced in comparison with $P$ control sample. On the other hand, an important change is not established for 28-d strengths values. However, mortar samples are not solidified at 2 day and strengths values are quite reduced at 7 day for $\mathrm{B}_{2} \mathrm{O}_{3} / c \geq 0.434$ ratio. $\mathrm{SA}$ and $\mathrm{CC}$ additives were added to mixture at rates of $1.0 \%, 1.5 \%, 2 \%$ by weight of cement due to suppressing this negative effect. With SA additive, 2-d compressive strengths of mortar samples increased at a $202 \%$ ratio in comparison with the $P$ control samples and 7-d compressive strengths of these samples also increased at a $266 \%$ ratio for $\mathrm{B}_{2} \mathrm{O}_{3} / c \geq 0.577$ ratio which is the highest ratio used in this study. Furthermore, 2 and 7 -d the flexural strengths of the same samples increased at $128 \%$ and $200 \%$ ratios in comparison with the control samples. As a result, the negative effect of boron compounds on the early strength of cemented composites was suppressed with SA additive.

\section{Acknowledgments}

This study was supported by the Süleyman Demirel University Scientific Research Project Coordination Unit (project No. 2573M10).

\section{References}

[1] I. Kula, A. Olgun, V. Sevinc, Y. Erdoğan, Cem. Concr. Res. 32, 227 (2002).

[2] Ş. Targan, A. Olgun, Y. Erdoğan, V. Sevinç, Cem. Concr. Res. 33, 1175 (2003).

[3] A. Sağlık, O. Sümer, E. Tunç, M.F. Kocabeyler, R.S. Çelik, "Boron Modified Active Belite (BAB) Cement and its Applicability for DSI Projects", DSI Technical Bulletin 105, Ankara 2009.

[4] D.E. Volkman, P.L. Bussolini, JTE 20, 84 (1992).

[5] D. Demir, G. Keleş, NIM-B 245, 501 (2006).

[6] BOREN, "Bor ve çimento", http://www.eie.gov. tr/duyurular/EV/EV_etkinlik/2008_bildiriler/ 04-0TURUM_veve_AR-GE/0403.pdf .

[7] A.G. Çelik, in: 27th Energy Efficiency Week Conference and Exhibition, Ankara 2008, p. 116 (in Turkish).

[8] M. Davraz, Sci. Eng. Compos. Mater. 17, 1 (2010).

[9] Monthly (November) Quality Control Test Report of BAB Cement, GOLTAS Cement Co. Operation, Isparta 2007.

[10] Monthly (April) Quality Control Test Report of Portland Cement, GOLTAS Cement Co. Operation, Isparta 2009.

[11] TS EN 196-1, "Methods of testing cement-Part 1: Determination of strength", TSE, Ankara 2002. 